\title{
Attitudes of undergraduates towards mental illness: A comparison between nursing and business management students in India
}

\author{
P Vijayalakshmi, ${ }^{1}$ RN, RM, MSN; D Reddy, ${ }^{1}$ MSW, MPhil, PhD (Schlor); S B Math, ${ }^{1}$ MD, DNB, PGDMLE; R Thimmaiah, ${ }^{2}$ MD \\ ${ }^{1}$ National Institute of Mental Health and Neuro Sciences, Bangalore, India \\ ${ }^{2}$ Department of Psychiatry, Dr BR Ambedkar Medical College, Bangalore, India
}

Corresponding author: P Vijayalakshmi (pvijayalakshmireddy@gmail.com)

\begin{abstract}
Background. Mental illness is an important public health issue worldwide; stigmatisation and negative attitudes towards people with mental illness are widespread among the general public. However, little is known about the attitudes of undergraduates to mental illness.

Purpose. To compare the attitudes towards mental illness among undergraduates enrolled in nursing courses v. those enrolled in Bachelor of Business Management (BBM) courses.

Methods. A cross-sectional descriptive design was adopted for the present study. A total of 268 undergraduates were selected to complete the Attitude Scale for Mental Illness (ASMI) and the Opinions about Mental Illness in the Chinese Community (OMICC) questionnaires.

Results. We found significant differences between the number of nursing and BBM students who agreed with statements posed by the questionnaires, e.g., that they would move out of their community if a mental health facility was established there $\left(\chi^{2}=16.503, p<0.002\right)$, that they were not afraid of treated mentally ill people $\left(\chi^{2}=15.279, p<0.004\right)$, and that people with mental illness tend to be violent $\left(\chi^{2}=14.215, p<0.007\right)$ and dangerous $\left(\chi^{2}=17.808, p<0.001\right)$. Nursing students disagreed that people with mental illness are easily identified $\left(\chi^{2}=30.094, p<0.000\right)$, have a lower IQ $\left(\chi^{2}=70.689, p<0.000\right)$ and should not have children $\left(\chi^{2}=24.531, p<0.000\right)$. Nursing students were more benevolent than BBM students, as they agreed that people with mental illness can hold a job $\left(\chi^{2}=49.992, p<0.000\right)$ and can return to their former position $\left(\chi^{2}=11.596\right.$, $\mathrm{p}<0.021)$, that everyone faces the possibility of becoming mentally ill $\left(\chi^{2}=38.726, p<0.000\right)$, and that one should not laugh at the mentally ill $\left(\chi^{2}=17.407, p<0.002\right)$. Nursing students held less pessimistic attitudes, as they felt that the mentally ill should receive the same pay for the same job $\left(\chi^{2}=10.669, p<0.031\right)$ and that the public are prejudiced towards people with mental illness $\left(\chi^{2}=17.604, p<0.001\right)$.

Conclusion. College students' attitudes towards people with mental illness vary based on the course that they are enrolled in. Attitudes may be positively improved by revising curriculum design to incorporate educational sessions about mental illness. These are essential steps to combat discrimination, and potentially enhance the promotion of human rights for the mentally ill.
\end{abstract}

S Afr J Psych 2013;19(3):66-73. DOI:10.7196/SAJP.398

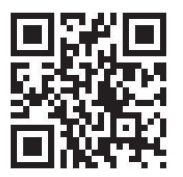

Worldwide, despite growing evidence of the importance of mental health for economic, social and human capital, people with mental health problems, mental health services and professionals, and even the very concept of mental health, receive negative publicity and are stigmatised in public perceptions. ${ }^{[1-3]}$ Today, the focus of psychiatric care is on de-institutionalisation: this depends on a number of key conditions, of which tolerance and non-discrimination are among the most important. ${ }^{[4]}$

As in other parts of the world, the prevalence of mental disorders in India is high. ${ }^{[5]}$ It is estimated that at least 58/1 000 Indians have a mental illness and about 10 million suffer from severe mental illness. ${ }^{[6-8]}$ In India, 90\% of people with psychiatric illnesses live with their families, and opinion about mental illness plays a vital role in their long-term care within the family and community. Further, a positive attitude towards mental illness is a prerequisite for the provision of holistic care. ${ }^{[9]}$ However, persistent negative attitudes and the social rejection of people with mental illness have prevailed throughout history. ${ }^{[10]}$ Studies show that people with mental illness face widespread stigmatisation, discrimination, violence, neglect and avoidance, and that negative attitudes towards them are widespread among the general public. ${ }^{[1-15]}$ Lack of awareness about mental illness encourages discrimination and stigmatisation. ${ }^{[16]}$ However, cross-sectional studies show that members of the public who have more knowledge about mental illness are less likely to endorse stigmatising attitudes. ${ }^{[15]}$

Every section of society has its unique way of perceiving mental illness, particularly the young generation and college-going students. Colleges may be the best place to develop a comprehensive mental health programme, because the attitude and values of college-going students tend to influence society the most. ${ }^{[17]}$ Thus, understanding the attitudes and beliefs about people with mental illness among undergraduate students is a fundamental step in addressing the negative attitudes so often reported in studies ${ }^{[15]} \mathrm{A}$ handful of studies have explored the attitudes among healthcare students and the effectiveness of 
training programmes. ${ }^{[18]}$ However, limited research is available regarding students' attitudes towards mental illness. Hence, the current study specifically aimed to examine the differences in attitudes towards mental illness of undergraduates studying nursing and those studying towards a Bachelor of Business Management (BBM). Because BBM students do not receive knowledge about the mental illness through clinical experience or course curriculum, it was hypothesised that a difference would be found between their attitudes and those of nursing students.

\section{Methods}

The study was carried out among undergraduate women from selected colleges of nursing and graduate women's colleges in Bangalore, India from April to June 2011.

\section{Participants}

A non-probability convenience sample with a quantitative descriptive method was used. Selection criteria for participants required that they be nursing or BBM students in the third year and fourth year of their course and willing to participate. There were no exclusion criteria. A total of 288 students were enrolled in the study, but 20 questionnaires were subsequently discarded as they were incomplete. Hence, 268 completed questionnaires (148 nursing students and 120 BBM students) were analysed.

\section{Instruments \\ Demographic data survey instrument}

The demographic form elicited information on five aspects of the participants' background: age, family's monthly income, place of residence, and history of personal contact with mental illness.

\section{Questionnaires}

The Attitude Scale for Mental Illness (ASMI) ${ }^{[19]}$ is a valid and reliable self-report that measures respondents' attitude to mental illness. It uses 34 items divided into six broad conceptual sub-scales:

- Benevolence, or paternalistic and sympathetic views

- Separatism, or attitude to discrimination

- Stereotyping, or the degree of social distance maintained from the mentally ill

- Restrictiveness, or perception of the mentally ill as a threat to society

- Pessimistic prediction, or level of prejudice towards mental illness

- Stigmatisation, or discriminatory behaviour towards those with mental illness.

Respondents are given the choice of 5 Likert scale responses (totally disagree $=1$, almost totally disagree $=2$, sometimes agree $=3$, almost totally agree $=4$, totally agree $=5$ ) based on their feelings towards each of the 34 items. The study also used the original version of the Opinions about Mental Illness in the Chinese Community (OMICC) questionnaire, ${ }^{[19]}$ in English.

\section{Procedure}

Both the ASMI and OMICC questionnaires were distributed to batches of students separately at various times, in a group setting in a common place such as the lecture halls. One author (PV) verbally explained the aims and method of the research and how to complete the questionnaires. The willing participants then completed both questionnaires in about 20 minutes.

\section{Ethical considerations}

Permission was obtained from the administrators of the colleges where the study was conducted. Participants were informed of the study's aims and procedures so that they could decide if they were willing to participate. It was explicitly explained that students' responses would have no influence on their semester exams. After students agreed to participate verbally the researcher gave them the confidential questionnaire. Data collection tools contained no identifying information and thus kept individual responses confidential.

\section{Statistical analysis}

The data were analysed using statistical software and results were presented in narratives and tables. Descriptive (frequency and percentage) and inferential statistics (chi-square test) were used to interpret the data. Statistical significance was assumed at $p<0.05$.

\section{Results}

A total of 268 undergraduate women participated. Nursing students comprised $55.2 \%(n=148)$ of the study population. The mean age ( \pm standard deviation) of nursing students was $19.5 \pm 1.62$ and the mean age of BBM students was $18.6 \pm 0.94$. The mean average income of the nursing students was (in thousands) Rs/- $1.21 \pm 16060.51$ and that of the BBM students was Rs/- 9.11 \pm 4 933.48. Approximately 33\% ( $n=49)$ of nursing compared with $29 \%$ ( $n=35)$ of BBM students came from rural areas $\left(\chi^{2}=17.698, p<0.000\right)$. Nursing students had more contact with mental illness than BBM students did $\left(\chi^{2}=12.594, p<0.000\right)$.

The results of comparative analysis of the responses to the ASMI scale of nursing students versus BBM students are listed in Table 1. On the Separatism sub-scale, more nursing students $(n=128,86.5 \%)$ than BBM students $(n=86,71.7 \%)$ disagreed with the statement: 'If a mental health facility is set up in my street or community, I will move out of the community' $\left(\chi^{2}=16.503, p<0.002\right)$. Similarly, more than half the nursing students $(n=79,53.4 \%)$ compared with $40 \%(n=48)$ of BBM students agreed that they were not afraid of treated mentally ill people $\left(\chi^{2}=15.279, p<0.004\right)$. Only $34.5 \%(n=51)$ of nursing and $21.6 \%$ $(n=26)$ of BBM students agreed that the law should allow a spouse to file for divorce when the other spouse is mentally ill $\left(\chi^{2}=11.892\right.$, $p<0.018)$. More nursing $(n=26,17.6 \%)$ than BBM students $(n=15$, $12.5 \%)$ disagreed with the statement that people with mental illness tend to be violent $\left(\chi^{2}=14.215, p<0.007\right)$ and dangerous $\left(\chi^{2}=17.808\right.$, $p<0.001)$. More nursing $(n=101,68.2 \%)$ than BBM students $(n=58$, $48.3 \%)$ felt that people with mental illness who are being treated are not more dangerous than normal people $\left(\chi^{2}=16.284, p<0.003\right)$.

Different attitudes were observed among nursing and BBM students on the Stereotyping sub-scale: $39.1 \%(n=58)$ of nursing students compared with $15.8 \%(n=19)$ of BBM students disagreed with the statement, 'It is easy to identify those who have a mental illness' $\left(\chi^{2}=30.094, p<0.000\right)$. Only $22.3 \%(n=33)$ of the nursing and $11.6 \%$ $(n=14)$ BBM students stated that 'people with mental illness cannot be easily identified by their behaviour $\left(\chi^{2}=3.892, p<0.008\right)$. A significant difference was observed in the reactions of nursing and BBM students to the statement 'People with mental illness have a lower IQ' $\left(\chi^{2}=70.689\right.$, 
Table 1. Participants' response to the Attitude Scale for Mental Illness (ASMI) questionnaire

\begin{tabular}{|c|c|c|c|c|c|c|c|c|}
\hline \multirow[b]{3}{*}{ Variable } & \multirow[b]{3}{*}{ Response } & \multicolumn{4}{|c|}{ Education } & \multirow[b]{3}{*}{$\chi^{2}$-value } & \multirow[b]{3}{*}{$d f$} & \multirow[b]{3}{*}{$p$-value } \\
\hline & & \multicolumn{2}{|c|}{ Nursing } & \multicolumn{2}{|c|}{ BBM } & & & \\
\hline & & $(n=148)$ & & $(n=120)$ & $\%$ & & & \\
\hline \multirow[t]{5}{*}{ People with mental illness have unpredictable behaviour } & Totally disagree & 2 & 1.4 & 4 & 3.3 & 4.812 & 4 & 0.307 \\
\hline & Almost totally disagree & 11 & 7.4 & 9 & 7.5 & & & \\
\hline & Sometimes agree & 73 & 49.3 & 65 & 54.2 & & & \\
\hline & Almost totally agree & 38 & 25.7 & 19 & 15.8 & & & \\
\hline & Totally agree & 24 & 16.2 & 23 & 19.2 & & & \\
\hline \multirow{5}{*}{$\begin{array}{l}\text { If people become mentally ill once, they will easily become } \\
\text { ill again }\end{array}$} & Totally disagree & 12 & 8.1 & 14 & 11.7 & 1.498 & 4 & 0.827 \\
\hline & Almost totally disagree & 19 & 12.8 & 13 & 10.8 & & & \\
\hline & Sometimes agree & 68 & 45.9 & 58 & 48.3 & & & \\
\hline & Almost totally agree & 31 & 20.9 & 22 & 18.3 & & & \\
\hline & Totally agree & 18 & 12.2 & 13 & 10.8 & & & \\
\hline \multirow{5}{*}{$\begin{array}{l}\text { If a mental health facility is set up in my street or } \\
\text { community, I will move out of the community }\end{array}$} & Totally disagree & 113 & 76.4 & 65 & 54.2 & 16.503 & 4 & $0.002^{*}$ \\
\hline & Almost totally disagree & 15 & 10.1 & 21 & 17.5 & & & \\
\hline & Sometimes agree & 11 & 7.4 & 24 & 20 & & & \\
\hline & Almost totally agree & 5 & 3.4 & 7 & 5.8 & & & \\
\hline & Totally agree & 4 & 2.7 & 3 & 2.5 & & & \\
\hline \multirow{5}{*}{$\begin{array}{l}\text { Even after a person with mental illness is treated, I would } \\
\text { still be afraid to be around them }\end{array}$} & Totally disagree & 54 & 36.5 & 26 & 21.7 & 15.279 & 4 & $0.004^{*}$ \\
\hline & Almost totally disagree & 25 & 16.9 & 22 & 18.3 & & & \\
\hline & Sometimes agree & 50 & 33.8 & 36 & 30 & & & \\
\hline & Almost totally agree & 11 & 7.4 & 17 & 14.2 & & & \\
\hline & Totally agree & 8 & 5.4 & 19 & 15.8 & & & \\
\hline \multirow{5}{*}{$\begin{array}{l}\text { Mental patients and other patients should not be treated in } \\
\text { the same hospital }\end{array}$} & Totally disagree & 34 & 23 & 19 & 15.8 & 6.276 & 4 & 0.179 \\
\hline & Almost totally disagree & 11 & 7.4 & 15 & 12.5 & & & \\
\hline & Sometimes agree & 29 & 19.6 & 21 & 17.5 & & & \\
\hline & Almost totally agree & 26 & 17.6 & 15 & 12.5 & & & \\
\hline & Totally agree & 48 & 32.4 & 50 & 41.7 & & & \\
\hline \multirow{5}{*}{$\begin{array}{l}\text { When a spouse is mentally ill, the law should allow for the } \\
\text { other spouse to file for divorce }\end{array}$} & Totally disagree & 36 & 24.3 & 25 & 20.8 & 11.892 & 4 & $0.018^{*}$ \\
\hline & Almost totally disagree & 14 & 9.5 & 25 & 20.8 & & & \\
\hline & Sometimes agree & 47 & 31.8 & 44 & 36.7 & & & \\
\hline & Almost totally agree & 18 & 12.2 & 13 & 10.8 & & & \\
\hline & Totally agree & 33 & 22.3 & 13 & 10.8 & & & \\
\hline \multirow[t]{5}{*}{ People with mental illness tend to be violent } & Totally disagree & 8 & 5.4 & 7 & 5.8 & 14.215 & 4 & $0.007^{\star}$ \\
\hline & Almost totally disagree & 18 & 12.2 & 8 & 6.7 & & & \\
\hline & Sometimes agree & 83 & 56.1 & 65 & 54.2 & & & \\
\hline & Almost totally agree & 29 & 19.6 & 15 & 12.5 & & & \\
\hline & Totally agree & 10 & 6.8 & 25 & 20.8 & & & \\
\hline \multirow[t]{5}{*}{ People with mental illness are dangerous } & Totally disagree & 22 & 14.9 & 14 & 11.7 & 17.808 & 4 & $0.001^{\star}$ \\
\hline & Almost totally disagree & 25 & 16.9 & 17 & 14.2 & & & \\
\hline & Sometimes agree & 83 & 56.1 & 52 & 43.3 & & & \\
\hline & Almost totally agree & 12 & 8.1 & 14 & 11.7 & & & \\
\hline & Totally agree & 6 & 4.1 & 23 & 19.2 & & & \\
\hline
\end{tabular}


Table 1 (continued). Participants' response to the Attitude Scale for Mental Illness (ASMI) questionnaire

\begin{tabular}{|c|c|c|c|c|c|c|c|c|}
\hline \multirow{4}{*}{$\begin{array}{l}\text { Variable } \\
\text { People with mental illness should be feared }\end{array}$} & \multirow{4}{*}{$\begin{array}{l}\text { Response } \\
\text { Totally disagree }\end{array}$} & \multicolumn{4}{|c|}{ Education } & \multirow{4}{*}{$\frac{\chi^{2}}{5.808}$} & \multirow{4}{*}{$\frac{d f}{4}$} & \multirow{4}{*}{$\frac{p \text {-value }}{0.214}$} \\
\hline & & \multicolumn{2}{|c|}{ Nursing } & \multicolumn{2}{|c|}{ BBM } & & & \\
\hline & & \multicolumn{2}{|c|}{$(n=148) \%$} & \multirow{2}{*}{$\frac{(n=120)}{35}$} & \multirow{2}{*}{$\frac{\%}{29.2}$} & & & \\
\hline & & 32 & 21.6 & & & & & \\
\hline & Almost totally disagree & 19 & 12.8 & 11 & 9.2 & & & \\
\hline & Sometimes agree & 67 & 45.3 & 41 & 34.2 & & & \\
\hline & Almost totally agree & 21 & 14.2 & 23 & 19.2 & & & \\
\hline & Totally agree & 9 & 6.1 & 10 & 8.3 & & & \\
\hline After people with mental illness are treated, they are still & Totally disagree & 74 & 50 & 37 & 30.8 & 16.284 & 4 & $0.003^{*}$ \\
\hline more dangerous than normal people & Almost totally disagree & 27 & 18.2 & 21 & 17.5 & & & \\
\hline & Sometimes agree & 31 & 20.9 & 47 & 39.2 & & & \\
\hline & Almost totally agree & 6 & 4.1 & 10 & 8.3 & & & \\
\hline & Totally agree & 10 & 6.8 & 5 & 4.2 & & & \\
\hline It is easy to identify those who have a mental illness & Totally disagree & 27 & 18.2 & 7 & 5.8 & 30.094 & 4 & $0.000^{*}$ \\
\hline & Almost totally disagree & 31 & 20.9 & 12 & 10 & & & \\
\hline & Sometimes agree & 48 & 32.4 & 36 & 30 & & & \\
\hline & Almost totally agree & 32 & 21.6 & 34 & 28.3 & & & \\
\hline & Totally agree & 10 & 6.8 & 31 & 25.8 & & & \\
\hline You can easily tell who has a mental illness by the & Totally disagree & 12 & 8.1 & 4 & 3.3 & 13.892 & 4 & $0.008^{*}$ \\
\hline characteristics of their behaviour & Almost totally disagree & 21 & 14.2 & 10 & 8.3 & & & \\
\hline & Sometimes agree & 43 & 29.1 & 36 & 30 & & & \\
\hline & Almost totally agree & 47 & 31.8 & 29 & 24.2 & & & \\
\hline & Totally agree & 25 & 16.9 & 41 & 34.2 & & & \\
\hline People with mental illness have a lower IQ & Totally disagree & 59 & 39.9 & 8 & 6.7 & 70.689 & 4 & $0.000^{*}$ \\
\hline & Almost totally disagree & 36 & 24.3 & 18 & 15 & & & \\
\hline & Sometimes agree & 31 & 20.9 & 24 & 20 & & & \\
\hline & Almost totally agree & 13 & 8.8 & 27 & 22.5 & & & \\
\hline & Totally agree & 9 & 6.1 & 43 & 35.8 & & & \\
\hline All people with mental illness have some & Totally disagree & 14 & 9.5 & 11 & 9.2 & 1.310 & 4 & 0.860 \\
\hline & Almost totally disagree & 20 & 13.5 & 11 & 9.2 & & & \\
\hline & Sometimes agree & 52 & 35.1 & 44 & 36.7 & & & \\
\hline & Almost totally agree & 40 & 27 & 34 & 28.3 & & & \\
\hline & Totally agree & 22 & 14.9 & 20 & 16.7 & & & \\
\hline It is not appropriate for a person with mental illness to get & Totally disagree & 30 & 20.3 & 18 & 15 & 8.528 & 4 & 0.074 \\
\hline married & Almost totally disagree & 25 & 16.9 & 10 & 8.3 & & & \\
\hline & Sometimes agree & 41 & 27.7 & 40 & 33.3 & & & \\
\hline & Almost totally agree & 26 & 17.6 & 19 & 15.8 & & & \\
\hline & Totally agree & 26 & 17.6 & 33 & 27.5 & & & \\
\hline Those who have a mental illness cannot fully recover & Totally disagree & 49 & 33.1 & 36 & 30 & 5.006 & 4 & 0.287 \\
\hline & Almost totally disagree & 36 & 24.3 & 21 & 17.5 & & & \\
\hline & Sometimes agree & 43 & 29.1 & 48 & 40 & & & \\
\hline & Almost totally agree & 10 & 6.8 & 10 & 8.3 & & & \\
\hline & Totally agree & 10 & 6.8 & 5 & 4.2 & & & \\
\hline
\end{tabular}




\section{ARTICLE}

Table 1 (continued). Participants' response to the Attitude Scale for Mental Illness (ASMI) questionnaire

\begin{tabular}{|c|c|c|c|c|c|c|c|c|}
\hline \multirow[b]{3}{*}{ Variable } & \multirow[b]{3}{*}{ Response } & \multicolumn{4}{|c|}{ Education } & \multirow[b]{3}{*}{$\chi^{2}$} & \multirow[b]{3}{*}{$d f$} & \multirow[b]{3}{*}{$p$-value } \\
\hline & & \multicolumn{2}{|c|}{ Nursing } & \multicolumn{2}{|c|}{ BBM } & & & \\
\hline & & $(n=148)$ & $\%$ & $(n=120)$ & $\%$ & & & \\
\hline \multirow[t]{5}{*}{ Those who are mentally ill should not have children } & Totally disagree & 82 & 55.4 & 40 & 33.3 & 24.531 & 4 & $0.000^{*}$ \\
\hline & Almost totally disagree & 31 & 20.9 & 23 & 19.2 & & & \\
\hline & Sometimes agree & 26 & 17.6 & 33 & 27.5 & & & \\
\hline & Almost totally agree & 6 & 4.1 & 6 & 5 & & & \\
\hline & Totally agree & 3 & 2 & 18 & 15 & & & \\
\hline \multirow[t]{5}{*}{ There is no future for people with mental illness } & Totally disagree & 98 & 66.2 & 69 & 57.5 & 4.995 & 4 & 0.288 \\
\hline & Almost totally disagree & 25 & 16.9 & 24 & 20 & & & \\
\hline & Sometimes agree & 15 & 10.1 & 13 & 10.8 & & & \\
\hline & Almost totally agree & 9 & 6.1 & 9 & 7.5 & & & \\
\hline & Totally agree & 1 & 0.7 & 5 & 4.2 & & & \\
\hline \multirow[t]{5}{*}{ People with mental illness can hold a job } & Totally disagree & 13 & 8.8 & 41 & 34.2 & 49.992 & 4 & $0.000^{*}$ \\
\hline & Almost totally disagree & 14 & 9.5 & 29 & 24.2 & & & \\
\hline & Sometimes agree & 52 & 35.1 & 29 & 24.2 & & & \\
\hline & Almost totally agree & 30 & 20.3 & 7 & 5.8 & & & \\
\hline & Totally agree & 39 & 26.4 & 14 & 11.7 & & & \\
\hline \multirow{5}{*}{$\begin{array}{l}\text { The care and support of family and friends can help } \\
\text { people with mental illness to get rehabilitated }\end{array}$} & Totally disagree & 4 & 2.7 & 4 & 3.3 & 23.204 & 4 & $0.000^{*}$ \\
\hline & Almost totally disagree & 5 & 3.4 & 4 & 3.3 & & & \\
\hline & Sometimes agree & 11 & 7.4 & 32 & 26.7 & & & \\
\hline & Almost totally agree & 26 & 17.6 & 27 & 22.5 & & & \\
\hline & Totally agree & 102 & 68.9 & 53 & 44.2 & & & \\
\hline \multirow{5}{*}{$\begin{array}{l}\text { Corporations and the community should offer jobs to } \\
\text { people with mental illness }\end{array}$} & Totally disagree & 4 & 2.7 & 28 & 23.3 & 41.046 & 4 & $0.000^{*}$ \\
\hline & Almost totally disagree & 8 & 5.4 & 11 & 9.2 & & & \\
\hline & Sometimes agree & 30 & 20.3 & 35 & 29.2 & & & \\
\hline & Almost totally agree & 32 & 21.6 & 18 & 15 & & & \\
\hline & Totally agree & 74 & 50 & 28 & 23.3 & & & \\
\hline \multirow{5}{*}{$\begin{array}{l}\text { After a person is treated for mental illness they can return } \\
\text { to their former job position }\end{array}$} & Totally disagree & 5 & 3.4 & 9 & 7.5 & 11.596 & 4 & $0.021^{*}$ \\
\hline & Almost totally disagree & 5 & 3.4 & 11 & 9.2 & & & \\
\hline & Sometimes agree & 34 & 23 & 38 & 31.7 & & & \\
\hline & Almost totally agree & 37 & 25 & 24 & 20 & & & \\
\hline & Totally agree & 67 & 45.3 & 38 & 31.7 & & & \\
\hline \multirow{5}{*}{$\begin{array}{l}\text { The best way to help those with a mental illness to recover } \\
\text { is to let them stay in the community and live a normal life }\end{array}$} & Totally disagree & 9 & 6.1 & 12 & 10 & 2.287 & 4 & 0.683 \\
\hline & Almost totally disagree & 8 & 5.4 & 5 & 4.2 & & & \\
\hline & Sometimes agree & 30 & 20.3 & 19 & 15.8 & & & \\
\hline & Almost totally agree & 35 & 23.6 & 28 & 23.3 & & & \\
\hline & Totally agree & 66 & 44.6 & 56 & 46.7 & & & \\
\hline \multirow{5}{*}{$\begin{array}{l}\text { After people with mental illness are treated and } \\
\text { rehabilitated, we still should not make friends with them }\end{array}$} & Totally disagree & 109 & 73.6 & 67 & 55.8 & 9.632 & 4 & $0.047^{*}$ \\
\hline & Almost totally disagree & 14 & 9.5 & 22 & 18.3 & & & \\
\hline & Sometimes agree & 14 & 9.5 & 17 & 14.2 & & & \\
\hline & Almost totally agree & 4 & 2.7 & 9 & 7.5 & & & \\
\hline & Totally agree & 7 & 4.7 & 9 & 7.5 & & & \\
\hline
\end{tabular}

continued ... 
Table 1 (continued). Participants' response to the Attitude Scale for Mental Illness (ASMI) questionnaire

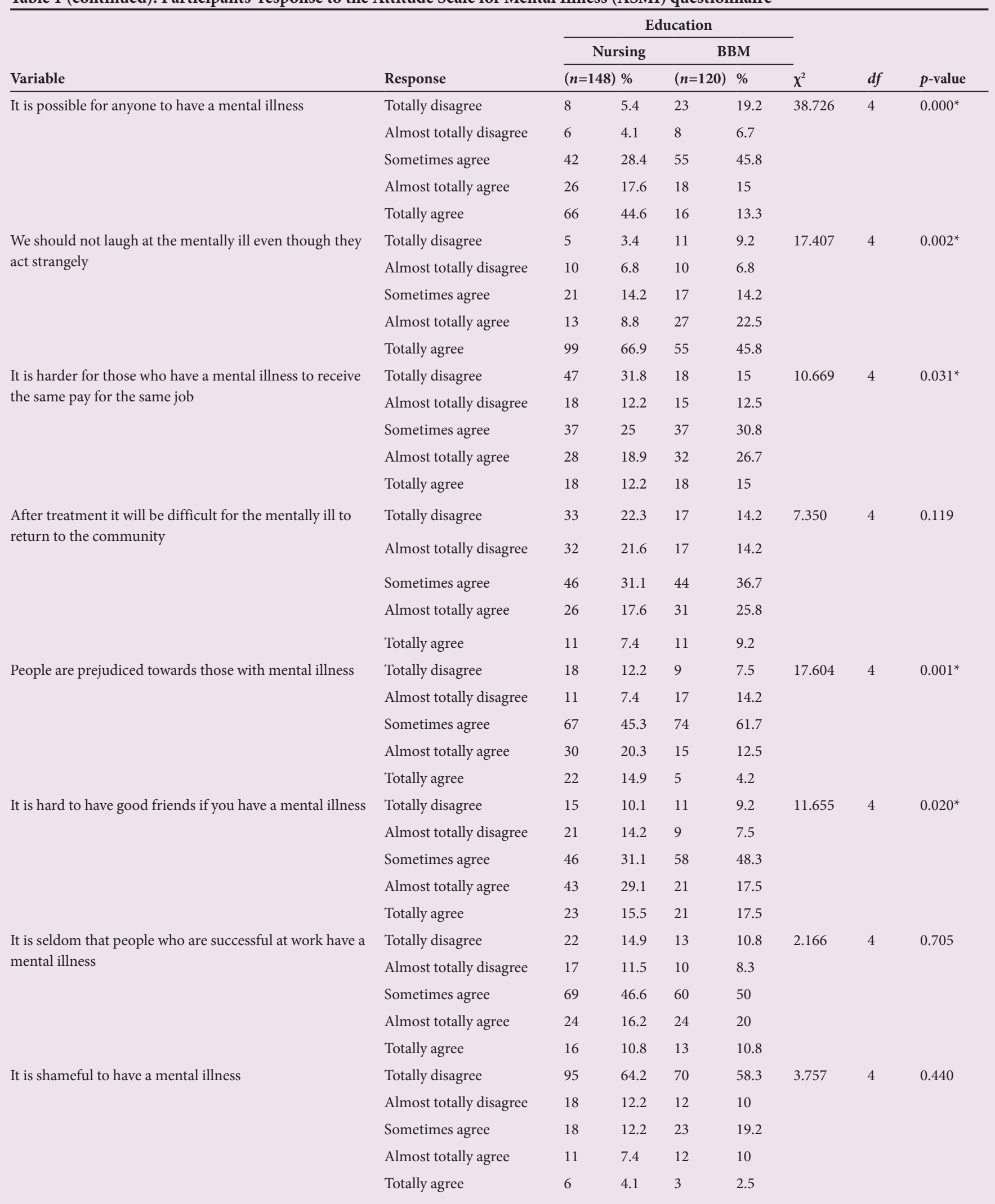

continued ... 


\section{$10 \times$ S $A<$

Table 1 (continued). Participants' response to the Attitude Scale for Mental Illness (ASMI) questionnaire

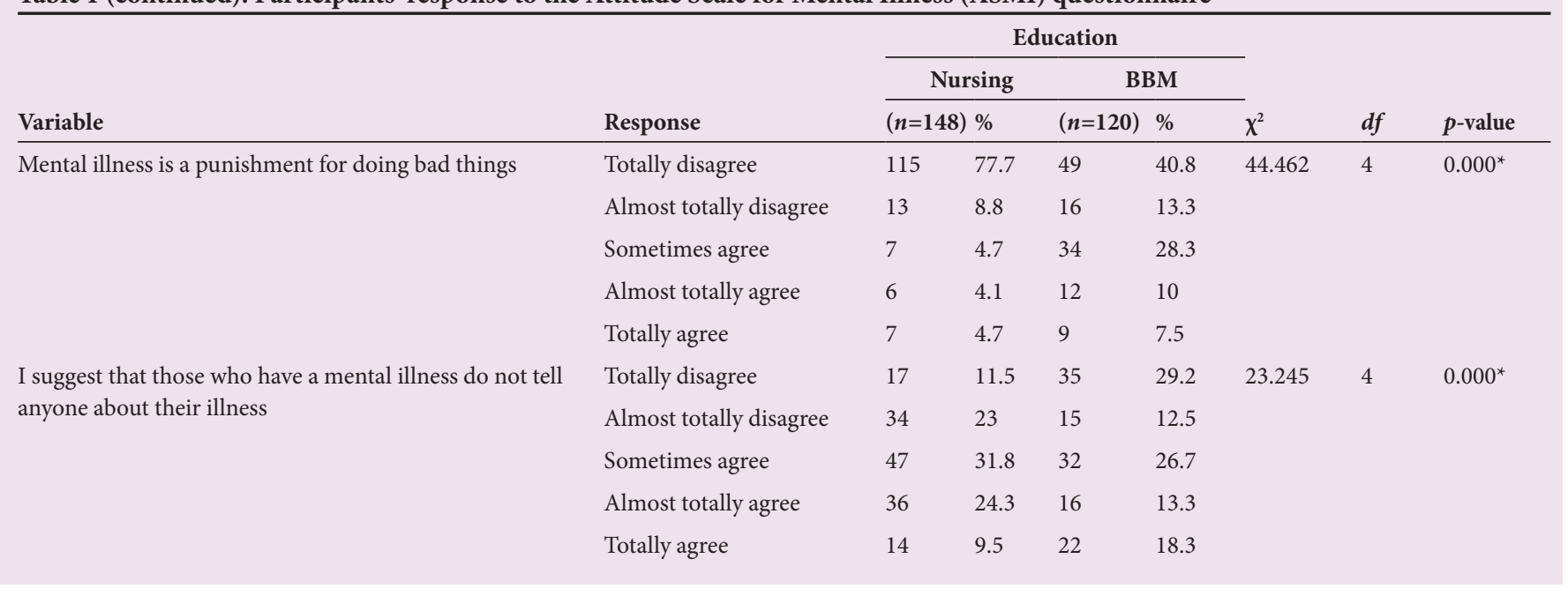

$p<0.000)$, with more nursing students $(n=95,64.2 \%)$ disagreeing than BBM students $(n=26,21.7 \%)$.

Nursing and BBM students responded similarly to statements in the Restrictiveness sub-scale. However, $76.3 \%(n=113)$ of nursing students compared to $52.5 \%$ ( $n=63$ ) of BBM students agreed that the 'mentally ill should be able to have children' $\left(\chi^{2}=24.531, p<0.000\right)$.

More nursing $(n=69,46.7 \%)$ than BBM students $(n=21,17.5 \%)$ agreed that 'people with mental illness can hold a job' $\left(\chi^{2}=49.992\right.$, $p<0.000)$. While the majority of both nursing $(n=128,86.5 \%)$ and BBM $(n=80,66.7 \%)$ students affirmed that 'family and friends can help the mentally ill to get rehabilitated' ( $\left.\chi^{2}=23.204, p<0.000\right), 38.3 \%$ $(n=46)$ of the BBM students disagreed with $71.6 \%(n=106)$ of the nursing participants that the mentally ill should be 'offered jobs by the corporation and community' $\left(\chi^{2}=41.046, p<0.000\right)$. However, the majority of both nursing $(n=104,70.3 \%)$ and BBM $(n=62,51.7 \%)$ students agreed that the 'treated mentally ill can return to their former job position' $\left(\chi^{2}=11.596, p<0.021\right)$. In the same way, $83.1 \%(n=123)$ of nursing and $74.1 \%(n=89)$ of BBM students felt that they could 'make friends with treated and rehabilitated persons with mental illness' $\left(\chi^{2}=9.632, p<0.047\right)$. More nursing $(n=92,62.2 \%)$ than BBM students $(n=34,28.3 \%)$ accepted that 'everyone faces the possibility of becoming mentally ill' ( $\left.\chi^{2}=38.726, p<0.000\right)$. The majority of both nursing $(n=112,75.7 \%)$ and BBM students $(n=82,68.3 \%)$ agreed that they 'should not laugh at the mentally ill' $\left(\chi^{2}=17.407, p<0.002\right)$.

Significant differences were also found in the Pessimistic Prediction sub-scale. A higher number of nursing $(n=65,44 \%)$ than BBM students $(n=33,27.5 \%)$ felt that 'the mentally ill should receive the same pay for the same job' $\left(\chi^{2}=10.669, p<0.031\right)$. More nursing $(n=52,35.2 \%)$ than BBM students $(n=20,16.7 \%)$ also agreed that 'people are prejudiced towards people with mental illness' $\left(\chi^{2}=17.604, p<0.001\right)$ and that it is 'hard for the mentally ill to have good friends' $\left(\chi^{2}=11.655, p<0.020\right)$.

More than three quarters of the nursing students $(n=115,77.7 \%)$ compared with only $40.8 \%$ ( $n=49)$ BBM students disagreed with the statement that 'mental illness is a punishment for doing bad things' $\left(\chi^{2}=44.462, p<0.000\right)$. Interestingly, more nursing students $(n=50$, $33.8 \%)$ than BBM students $(n=38,31.6 \%)$ felt that the 'mentally ill should not disclose their illness' $\left(\chi^{2}=23.245, p<0.000\right)$.

\section{Discussion}

The current study indicates that nursing students generally hold more positive attitudes towards all aspects of mental illness than BBM students. It is likely that the attitudes of nursing students and other health professionals may be more positive than those of BBM students and the general public, since they have fieldwork experience and are interested in working within mental health. Nursing and other healthcare students are knowledgeable about mental health, have a greater awareness of mental health issues, and are trained in skills that enable them to cope with challenging behaviour displayed by mentally ill patients and to provide them with care. The training programmes they undergo ${ }^{[20,21]}$ and contact with people with mental disorders lead to more positive attitudes and enlightened views. ${ }^{[18,22-24]}$ Similarly, a study on occupational therapy students reported that they were positively influenced towards persons with disabilities after having contact with disabled persons through fieldwork. ${ }^{[25]}$ Furthermore, a multicentre university programme that surveyed 456 students from various departments reported that they developed less stigmatising attitudes after a course on mental illness. ${ }^{[26]}$

However, not all healthcare students exhibit this positive attitude towards mental illness. A recent investigation, which explored student nurses' attitudes towards psychiatric/mental health nursing as a career, found that students were negative about the prospect of working in this area. ${ }^{[27]}$ The authors concluded that this was a direct result of negative attitudes towards mental health service users. Another study, which examined the impact of the psychiatric curriculum on the attitude of Indian undergraduate medical students and interns, found that the participants were more negatively disposed towards accepting the autonomy and independence of the mentally ill and in considering them as part of the larger unaffected community. ${ }^{[28]}$

It is integral to recognise the value of changing attitudes and perceptions to promote equality and inclusion for people with mental illness. There is a need to educate all students about mental health disorders, through interventions such as discussions, talks, and awareness sessions in class and tutorials. A recent study examined the effects of three strategies for changing stigmatising attitudes about schizophrenia and other severe mental illnesses among 152 randomly 
selected college students: (i) education (which replaces myths about mental illness with accurate conceptions); (ii) contact (which challenges public attitudes about mental illness through direct interactions with persons who have these disorders); and (iii) protest (which seeks to suppress stigmatising attitudes about mental illness). ${ }^{[29]}$ The researchers found that contact stimulated more positive changes in ideas about targeted psychiatric disabilities, i.e. depression and psychosis, than education did. Other research also provided strong evidence that contact with the mentally ill reduced stigmatised attitudes among the general population. ${ }^{[30]}$ Another study explored the factors which might influence the willingness of teenage students to address mental health concerns: results suggested that reducing stigma through mental health education is crucial. ${ }^{[31]}$ Further, outreach programmes that are designed to enhance college students' help-seeking attitudes and intentions, and to reduce stigmas, were effective in increasing participants' positive attitudes toward counselling and decrease their self-stigma associated with counselling immediately after the programme. ${ }^{[32]}$

In this study, nursing students had less restrictive, more benevolent attitudes than BBM students. The majority agreed that people with mental illness can have children and acknowledged their need for job opportunities. Stigma related to mental illness is an international concern, and research is needed to understand its basis, mechanisms and consequences in order to formulate means by which stigma and its impact may be ameliorated. ${ }^{[33]}$ Stigma diminishes self-esteem and robs people of social opportunities such as employment or accommodation. ${ }^{[34]}$ Perhaps unfortunately, in the present study many nursing students felt that people with mental illness should not disclose their illness to others. These findings could be attributed to nursing students' awareness of how the impact of stigma can pervade the lives of people with mental health problems in many different ways.

The present study has certain limitations. As the participants were selected through purposive sampling and were primarily women, gender differences could not be examined. The results are therefore not generalisable and are not directly comparable to most other studies. Furthermore, given that attitudes toward mental illness are culturally and socially sensitive, caution is required when comparing results across different contexts. The study lacked a qualitative component, which may have provided more personal data regarding students' attitudes and understanding of mental illness. However, despite these limitations, we believe this study contains important findings for researchers as well as practitioners working in the field of mental health.

\section{Conclusion}

This study revealed that nursing students exhibited a significantly more positive attitude towards mental illness compared to BBM students. Efforts must be made to improve the attitudes of college students not in contact with mental illness, through raising awareness of mental health issues, providing educational sessions, and making time for discussion. Hence, the researchers strongly suggest the curriculum be revised to incorporate educational sessions about mental illness, in order to combat stigma and discrimination, and potentially promote the human rights of the mentally ill.

Acknowledgements. We thank the participants for contributing to this study.

\section{References}

1. Beddington J, Cooper CL, Field J, et al. The mental wealth of nations. Nature 2008;455(7216):1057 1060. [http://dx.doi.org/10.1038/4551057a]

2. Sartorius N, Schulze H. Reducing the Stigma of Mental Illness: A Report From a Global Programme of the World Psychiatric Association. Geneva: World Health Organization, 2006.

3. Sadik S, Bradley M, Al-Hasoon S, Jenkins R. Public perception of mental health in Iraq. Int J Ment Health Syst 2010;4:26. [http://dx.doi.org/10.1186/1752-4458-4-26]

4. Hannigan B. Mental healthcare in the community: An analysis of contemporary public attitudes towards, and public representations of, mental illness. J Ment Health 1999;8(5):431-440.

5. Kermode M, Bowen K, Arole S, Joag K, Jorm AF. Community beliefs about causes and risks for mental disorders: A mental health literacy survey in a rural area of Maharashtra, India. Int J Soc Psychiatr 2010;56(6):606-622. [http://dx.doi.org/10.1177/0020764009345058]

6. Raguram R, Weiss MG, Keval H, Channabasavanna SM. Cultural dimensions of clinical depression in Bangalore, India. Anthropology Med 2001;8:31.

7. Math SB, Chandrashekar CR, Bhugra D. Psychiatric epidemiology in India. Ind J Med Res 2007;126(3):183-192.

8. Khandelwal SK, Jhingan HP, Ramesh S, Gupta RK, Srivastava VK. India mental health country profile. Int Rev Psychiatr 2004;16:126-141.

9. World Health Organization. Atlas: Nurses in Mental Health 2007. Geneva: WHO, 2007. www.who.int/ mental_health/evidence/nursing_atlas_2007.pdf (accessed 19 November 2012).

10. Luty J, Okon U, Mohammed S, Arghya S. Effectiveness of Changing Minds campaign factsheets in reducing stigmatised attitudes towards mental illness. The Psychiatrist 2007;31:377-381. [http://dx.doi. org/10.1192/pb.bp.106.012443]

11. Jorm AF, Korten AE, Jacomb PA, Christensen H, Henderson S. Attitude towards people with a mental disorder: A survey of the Australian public and health professionals. Aust N Z J Psychiatr 1999;33(1):77-83.

12. Byrne P. Psychiatric stigma: Past, passing and to come. J R Soc Med 1997;90(11):618-621.

13. Porter R. Can the stigma of mental illness be changed? Lancet 1998;352(9133):1049-1050. [http:// dx.doi.org/10.1016/S0140-6736(98)07155-4]

14. Nordt C, Rössler W, Lauber C. Attitudes of mental health professionals toward people with schizophrenia and major depression. Schizophr Bull 2006;32:709-714.

15. Link B, Struening EL, Rahav M, Phelan JC, Nuttbrock L. On stigma and its consequences: Evidence from a longitudinal study of men with dual diagnoses of mental illness and substance abuse. J Health Soc Behav 1997;38(2):117-190.

16. Wolff G, Pathare S, Craig T, Leff J. Community knowledge of mental illness and reaction to mentally ill people. Br J Psychiatry 1996;168(2):191-198.

17. Mahto RK, Verma PK, Verma AN, Singh AR, Chaudhury S, Shantna K. Students' perception about mental illness. Ind Psychiatry J 2009;18(2):92-96. [http://dx.doi.org/10.4103/0972-6748.62267]

18. Boyle MJ, Williams B, Brown T, et al. Attitudes of undergraduate health science students towards patients with intellectual disability, substance abuse, and acute mental illness: A cross-sectional study. BMC Med Educ 2010;10:71. [http://dx.doi.org/10.1111/10.1186/1472-6920-10-71]

19. Ng P, Chan KF. Sex differences in opinion towards mental illness of secondary school students in Hong Kong. Int J Soc Psychiatry 2000;46(2):79-88.

20. Ng P, Chan KF. Attitudes towards people with mental illness. Effects of a training program for secondary school students. Int J Adoles Med Health 2002;14(3):215-224.

21. Pitre N, Stewart S, Adams S, Bedard T, Landry S. The use of puppets with elementary school children in reducing stigmatizing attitudes towards mental illness. J Ment Health 2007;16(3):415-429.

22. Hamaideh S, Mudallal R. Attitudes of Jordanian nursing students towards mental illness: The effect of teaching and contact on attitudes change. College Student Journal. 2009;43(2):335-346.

23. Addison SJ, Thorpe SJ. Factors involved in the formation of attitudes towards those who are mentally ill. Social Psychiatry Psychiatric Epidemiology 2004;39:228-234.

24. Ng SL, Martin JL, Romans SE. A community's attitude towards the mentally ill. New Zeland Medical Journal 1995;108:505-508.

25. Estes JP, Deyer CA, Hansen RA, Russell JC. Influence of occupational therapy curricula on students' attitudes toward persons with disabilities. Am J Occup Ther 1991;45(2):156-159.

26. Gyllensten AL, Svensson B, Björkman T, et al. Attitudes in healthcare students towards mental illness: A pre and post multicenter university program survey. The Internet Journal of Allied Health Sciences and Practice 2011;9(3):(epub).

27. Aggarwal NR. Attitudes of students towards people with mental ill health and impact on learning and well-being. Journal of Research in Special Educational Needs 2012;12(1):37-44. [http://dx.doi. org/10.1111/j.1471-3802.2010.01193.x]

28. Lingeswaran A. Psychiatric curriculum and its impact on the attitude of Indian undergraduate medical students and interns. Indian J Psychol Med 2010;32(2):119-127.

29. Corrigan PW, River LP, Lundin RK, et al. Three strategies for changing attributions about severe mental illness. Schizophr Bull 2001;27(2):187-195.

30. Alexander LA, Link BG. The impact of contact on stigmatizing attitudes towards people with mental illness. J Ment Health 2003;12(3):271-289.

31. Chandra A, Minkowitz CS. Factors that influence mental health stigma among 8th grade adolescents. I Youth Adolescence 2007;36:763-774. [http://dx.doi.org/10.1007/s10964-006-9091-0]

32. Blocher WG. Effectiveness of an outreach program designed to enhance college students' helpseeking attitudes, intentions, and to reduce stigmas. Graduate Thesis. Ames, Iowa: Iowa State University, 2011.

33. Ku TK. Culture and stigma towards mental illness: A comparison of general and psychiatric nurses of Chinese and Anglo-Australian backgrounds. Masters Thesis. Melbourne: University of Melbourne, 2007.

34. Corrigan P. How stigma interferes with mental healthcare. Am Psychol 2004;59(7):614-625. [http:// dx.doi.org/10.1037/0003-066X.59.7.614] 